TAO, Vol. 15, No. 5, 983-998, December 2004

\title{
A Composite Comparative Study of the Dust Events in Taipei and Beijing
}

\author{
Koung-Ying Liu ${ }^{1, *}$ and Ling-Feng Hsiao ${ }^{2}$ \\ (Manuscript received 1 July 2003, in final form 31 July 2004)
}

\begin{abstract}
The purpose of this study was to identify predictors of dust events. A longitudinal study of dust events that occurred in Taipei and Beijing from 2000 to 2002 was investigated. The events were separated into two groups. Group 1 was the dust events, which affected Beijing, and Group 2 was dust events, which affected Taipei. The separation of dust events by the position and extension of the polar continental high was determined. Composite analysis of geopotential height, $850 \mathrm{hPa}$ vorticity and principal components (PC) were then carried out for these two categories. Comparisons of the East Asian main trough distributions, for high-low and negative-positive vorticity demonstrated differences between both of categories. PC analysis revealed that both geopotential height and wind field, for the first two principal components (PC1 and PC2) of Group 1 and Group 2 were also quite different and that the total variance ratio was greater than $90 \%$. The results indicated that the position of the polar high in both cases was similar. The extension of the high that influenced Beijing however covered an area to the north of the Yellow River and that which influenced Taipei, covered an area to the south of the Yellow River. The results also indicated that the trough (PC1) and the cyclonic circulation (PC2) were stronger in Group 2 than Group 1.
\end{abstract}

(Key words: Blowing dust, Dust storm, Principal Components analysis)

${ }^{1}$ Department of Atmospheric Science, Private Chinese Culture University, Taipei, ROC

${ }^{2}$ Research Center for Environmental Change, Academia Sinica, Taipei, ROC

* Corresponding author address. Prof. K. Y. Liu, Department of Atmospheric Science, Private Chinese Culture University, Taipei, ROC; E-mail: kyliu@atmos.pccu.edu.tw 


\section{INTRODUCTION}

Blowing dust (BD) from arid land can be transported downwind over an extended area. An increase in the dust population for the affected area, during a BD episode, depends on the surface conditions and the surface wind speed in the source region (Liu et al. 2004), the longrange transport and the deposition process. All of these factors are related to seasonal and synoptic conditions, and so to climatic conditions and the controlling weather system. From winter through to early spring the mean position of the Asian polar continental air mass (Cp) and the related cold high pressure center is either over the region south to south-south east of Lake Baikal (Liu et al. 2002) or over the Mongolian region. Generally the lower boundary is situated over level loess land or desert and the forward boundary of the high, over Inner Mongolia to Huangtu Gaoyuan (Loess Plateau or Yellow-Sand Plateau). When a thermal low is established in this region before the cold high, due to an increase in temperature, the constant low relative humidity of very dry air, over the area, becomes even drier. This forms suitable conditions for yellowish blowing dust as the $\mathrm{Cp}$ breaks out with gusty wind. There are many similar areas over the world and between 1 and 3 billion tons of dust fly up into the sky annually and precipitate all over the globe (Holmes 2001).

Due to the degeneration of surface coverage of China's grand northwest high land, the threat of yellow dust is steadily increasing. In several cases, veil-like dust clouds were observed to be transported as far as the west coast of the United States (Duce et al. 1980; Parrinton et al. 1983). The dust clouds, not only affect short-term air quality and human health, but have also been linked to global climate changes. The influence on Taiwan has also increased (Chen et al. 2004; Chou et al. 2004; Lin et al. 2004). Therefore, many specific case studies of longrange transport and related hazards have been carried out (Chen and Chen 1987; Yu et al. 1996; Lee 1998; Lee and Hsu 1998; Liu 2002; Hsiao et al. 2001; Liu 2002; Liu et al. 2002; Chen et al. 2004; Chen and Wann 2004: Chou et al. 2004; Lin et al. 2004). The results of these studies indicate that specific weather patterns favor the occurrence of dust events over Taiwan. In order to understand these events and to assay their forecast potential, the EPA supported an investigation into these events from 2000 - 2003. The results of this investigation indicate that even though there was a difference in the synoptic conditions for each case, there were also similarities. In June 2003, twenty-four speakers, from both sides of the Taiwan Strait, presented studies and discussion on dust events at a conference held by the National Committee on Mongolia-Tibet Affairs in Taipei, and the published proceedings of this conference were also a useful reference for this study.

In order to understand the general conditions of a group of similar events, composite and principal components (PC) analysis were used. These methods were useful because they filtered out variations and revealed the main features in all cases. Therefore, all dust events that occurred in Taipei over the last three years were selected according to the observed records of $\mathrm{PM}_{10}$ for this study and NCEP reanalysis data was used, when composite analysis was carried out. In addition, cases that affected Beijing (Wang et al. 2000), but not Taiwan, were also studied and discussed, using the same procedure. A comparative study was then carried out and these results demonstrated potential indicators to forecast yellow dust events in Taipei. 


\section{SYNOPTIC DESCRIPTION}

According to Chien et al. (2002) the primary source of the dust events, which occurred in China from 1952 - 2001, were within an elongated area, southeast to south of the continental high, with it's major axis ranging from approximately $\sim 113^{\circ} \mathrm{E}$, along $\sim 40^{\circ} \mathrm{N}$, westward to $\sim 82^{\circ} \mathrm{E}$. When the intensity of the high increased to a certain extent, dynamic instability led to an outbreak of cold air and a surface wind speed of up to $6-9 \mathrm{~m} \mathrm{~s}^{-1}$. These conditions resulted in blowing dust. This event has the potential to completely obscure the sky and in its extreme form, cause a dust storm. Poor stability can cause particles in the storm to be transported by eddies to the middle troposphere, where a layer of stable air tends to stop the vertical transport, creating a sharply defined upper limit of the dust layer, which can be observed by satellite (Liu and Lin 2004). This observation indicates the coverage and the severity of a dust event and these particular conditions denote a mid-latitude weather system, composed of the Mongolia high and associated with a leading cyclone, in the area under consideration.

In 1906, Margules pointed out that the average frictionless wind speed developed in two air masses is proportional to the root of the temperature difference between them and the thickness of the downward motion in the cold air region (Hess 1959). Subsequent investigations revealed (Palmen and Newton 1969) a clearer mechanism of kinetic energy, wind speed and production of the mid-latitude high and low system. In a cold core system the kinetic energy is produced when there is upper level convergence and lower level divergence. Under these conditions, the maximum kinetic energy transport occurs within the transition zone of the high (cold air) and the low (warm air). Accordingly, the high is the major sustaining contributor in the middle latitude high and low system (Hess 1959). Therefore, if there is a thermal low in front of the cold high for both pressure and temperature gradients, then the static instability of the related region will be very large. As a result, the local wind and the vertical motion will increase systematically.

Xiao et al. (1997) selected five extreme historical cases in China and composed the 0000 UTC weather charts just before the occurrence of the blowing dust events (Fig. 1). Their results revealed that the system was a baroclinic one and, on the surface, the pressure gradient between the high $(\mathrm{G})$ and low (D) was very strong. Under these circumstances, the surface wind must be considerably stronger and accompanied by an ageostrophic wind. The vertical component of an ageostrophic wind blows across isotherms toward colder air in an upward motion and directed toward warmer air in a downward motion. This behavior tilts the boundary of the two air masses, along with the cold front and dust wall, between the high and the low, i.e. between the cold and warm air (Carlson 1994). The degree of this tilt is inversely proportional to the horizontal temperature gradient.

From 2000 to 2002, ten yellow dust events occurred in Taipei and fourteen in Beijing (Table 1). According to previous studies, the continental high and its leading cyclone are the two major contributors of dust events. The long-range transport, however, was thought to be dependent upon advection or the flow pattern of the lower troposphere. In this paper these dust events were reanalyzed and separated into two groups depending on whether they affected Taipei or Beijing. Each group was classified into three sub-groups based on synoptic patterns. Sub-group 1 denotes a continental high extending or moving eastward from the source region 
towards the shore along a path, north of the Yellow River. Sub-group 2 is similar to 1 but denotes a path, south of the Yellow River. Sub-group 3 denotes a migrating high, separated from the continental high, moving southeastward to Taiwan. These results are shown in Table 1.

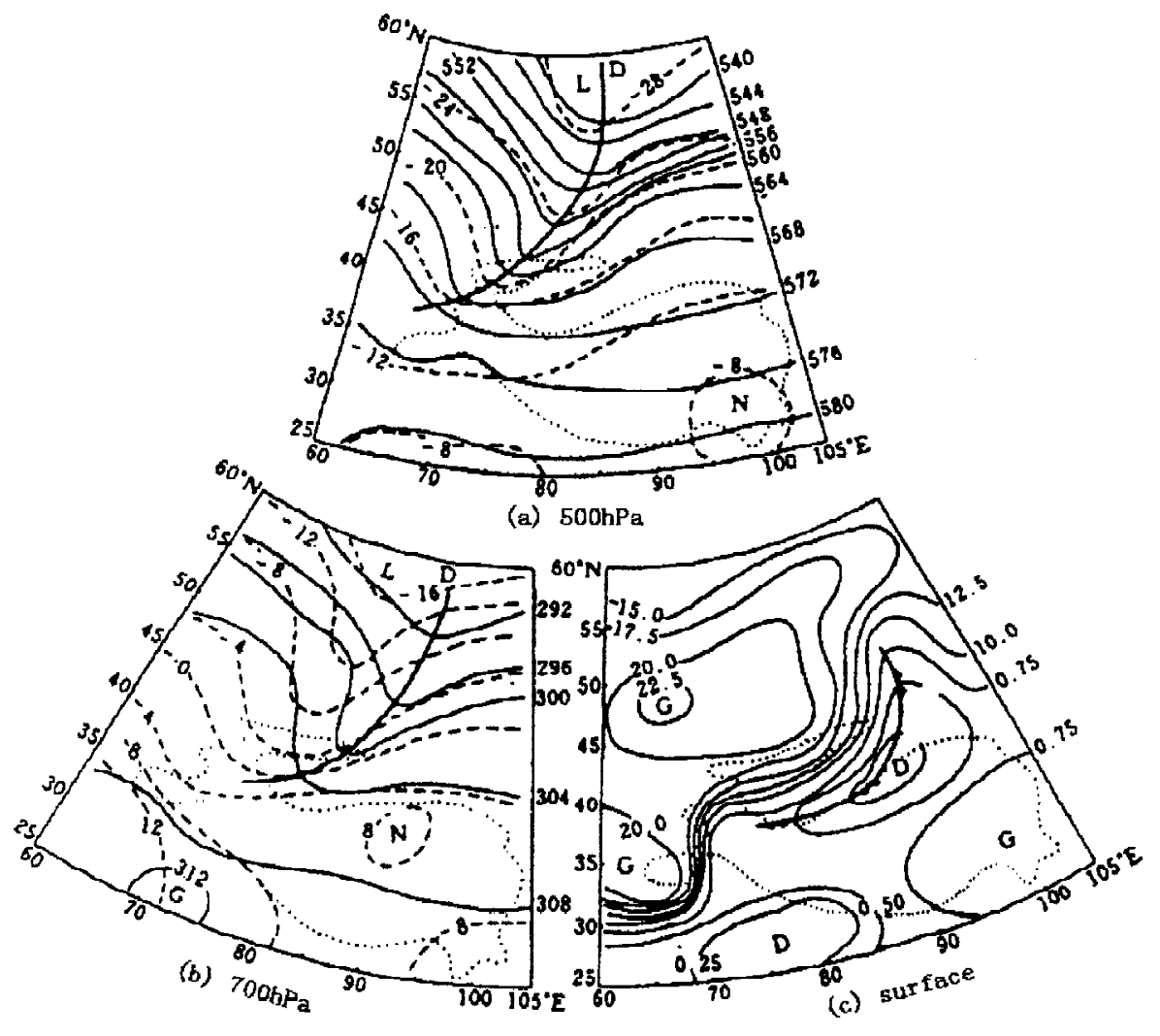

Fig. 1. Surface, 700 and $500 \mathrm{hPa}$ composite charts (0000UTC, event days) of five severe dust storms that occurred in China (Xiao et al. 1997).

\section{COMPOSITE AND PC ANALYSIS}

There are several methods for examining the relationships between general weather characteristics and selected synoptic features, which provide simple, but effective, exploratory tools. One procedure is to construct a composite map by averaging variables for individual cases of selected weather conditions. Special features are emphasized and easy to identify from the composite map.

Of the twenty-four dust events that occurred in Mainland China, during 2001 and 2002, fourteen cases affected Beijing. Twelve of these belonged in the first subgroup and two of these went on to affect Taipei. Six out of the ten dust events that affected Taipei, during this time, belonged in the second sub-group, one of which also affected Beijing on its way to 
Taipei. In order to understand the difference between these two groups, composite synoptic charts, of $1000 \mathrm{hPa}, 700 \mathrm{hPa}$, and $500 \mathrm{hPa}$, were completed for the twelve and six cases, prior to the occurrence of the dust events. The components of the composite charts were the geopotential height fields of each layer and the relative vorticity field of the layer at $850 \mathrm{hPa}$. NCEP reanalysis data was used for composite analysis.

Table 1. Yellow dust events of Taipei and Beijing during 2000 2002.

\begin{tabular}{ccc}
\hline Time & $\begin{array}{c}\text { Affect area } \\
\text { (Taipei or Beijing) }\end{array}$ & Classification \\
\hline 2000.03 .02 & $\mathrm{~B}$ & 1 \\
2000.03 .17 & $\mathrm{~B}$ & 1 \\
2000.03 .22 & $\mathrm{~T}$ & 3 \\
2000.03 .29 & $\mathrm{~T}$ & 2 \\
2000.04 .03 & $\mathrm{~B}$ & 1 \\
2000.04 .05 & $\mathrm{~B}$ & 1 \\
2000.04 .08 & $\mathrm{~B}$ & 1 \\
2000.04 .19 & $\mathrm{~B}$ & 1 \\
2000.04 .27 & $\mathrm{~T}$ & 2 \\
2001.03 .02 & $\mathrm{~B}$ & 1 \\
2001.03 .04 & $\mathrm{~T}$ & 2 \\
2001.03 .18 & $\mathrm{~B}$ & 3 \\
2001.03 .21 & $\mathrm{~B}$ & 2 \\
2001.03 .23 & $\mathrm{~B}$ & 1 \\
2001.04 .05 & $\mathrm{~B}$ & 1 \\
2001.04 .07 & $\mathrm{~B}$ & 1 \\
2001.04 .12 & $\mathrm{~T}$ & 2 \\
2001.05 .02 & $\mathrm{~T}$ & 2 \\
2001.05 .11 & $\mathrm{~B}$ & 1 \\
2002.02 .11 & $\mathrm{~T}$ & 2 \\
2002.03 .18 & $\mathrm{~T}$ & 1 \\
2002.03 .23 & $\mathrm{~B}$ & 1 \\
2002.04 .09 & $\mathrm{~T}$ & 1 \\
2002.04 .18 & $\mathrm{~T}$ & \\
\hline
\end{tabular}

Note: B and T represent Beijing and Taipei, respectively. Numbers 1, $2 \& 3$ denote synoptic patterns for sub-groups $1,2 \& 3$, respectively 
Principal components (PC) were also used to classify the weather maps. This technique provided for new combinations of one or more physical characteristics of a selected variable or variables. Measurements of selected variables for analysis were organized in a data matrix. The data matrix, of geopotential height and wind vector for each grid point was converted into a square matrix of either covariance or correlation coefficients between each of the $n$ variables over $\mathrm{N}$ cases. Dimensions of original data were reduced then to the maximum degree possible, from which new variables, i.e., principal components, were computed (Barry and Perry 1974).

\section{RESULTS AND DISCUSSION}

\subsection{Geopotential Field}

Figures 2 and 3 depict composed geopotential height charts for the two groups. The differences between them are summarized in Table 2. Among the many differences, the most pronounced were coverage of the continental high, the strength of the east coast major trough as well as the short trough over Central China.

\subsection{Vorticity Field}

Vorticity is another indicator of a synoptic system. Figures 4 and 5 represent the $850 \mathrm{hPa}$ mean spatial distribution of vorticity for Group 1 and 2, respectively. A comparison of Figs. 4 and 5 indicates a positive vorticity center (sheded) over the Japanese sea, along the East Asian major trough, for the six cases, affecting Taipei, depicted in the composite chart of Fig. 4. This positive vorticity area extended from the center to the northeast of Taipei. In addition, a negative center (within dot lines) was noted on the east coast of Mainland China, covering an area extending from the center, near the river mouth of Yang-Tze river, north-northwestward to the west of Lake Bekal, Another minor positive center was located to the east of Lake Bekal. This type of configuration indicates that the air invading Taipei came from the Loess Plateau. The cases, which affected Beijing, depicted in Fig. 5, indicate that the positive vorticity center relative to the major trough was much weaker and located further eastward, with an orientation more or less northeast to southwest. Another positive center was also located over the east region of Lake Bekal, and between the two, there was a weaker negative vorticity area over north to northwest China. These results indicate that when Beijing was affected by dust events, it was under the control of a weak continental high, while Taipei was unaffected because it was still covered by the Pacific high.

\subsection{PC Analysis}

Figures 6 and 7 are the composite PC charts of cases, which influenced Beijing and Taipei, respectively. These charts indicate firstly, that there was a high correlation for both geopotential height and wind vector of each grid point, secondly that the trough along east coast of Mainland China was much stronger for Group 2 (see Fig. 7) than for Group 1 (see Fig. 6) and thirdly, that the northern wind in cases invading Taipei was very strong, as indicated by PC2. 
All these characteristics favor forecast of a dust event; that is whether or not it will invade Taipei. PC analysis also demonstrated that clear differences exist between the two synoptic patterns, most importantly differences in the position of the continental high, in the strength of the major trough and the northern wind speed.

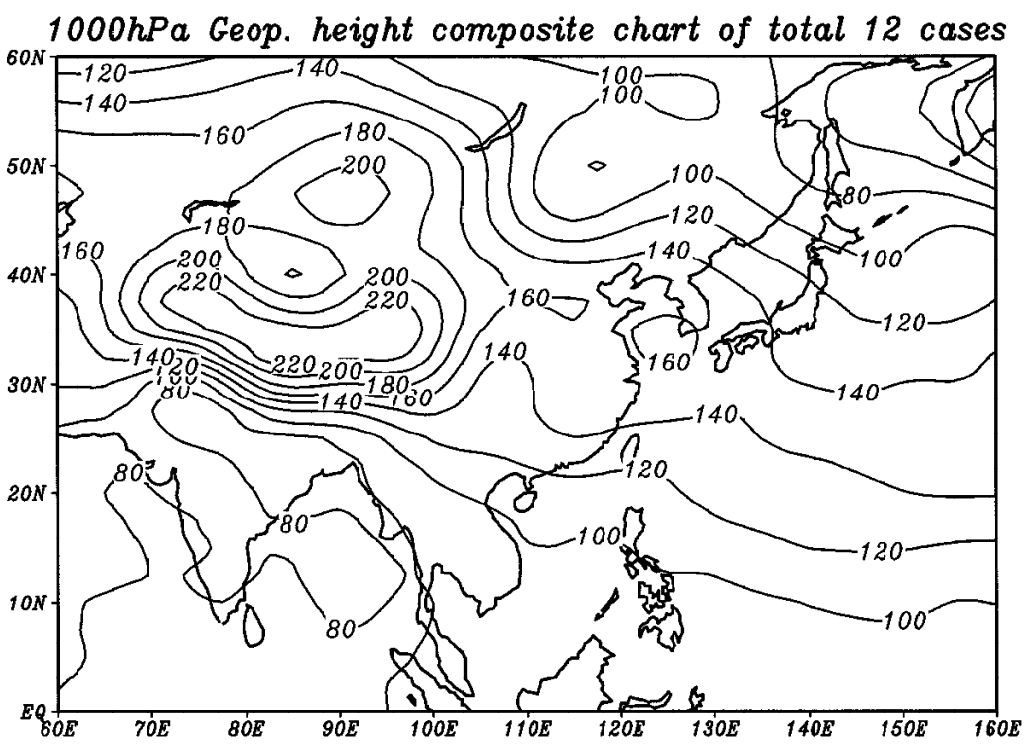

(a)

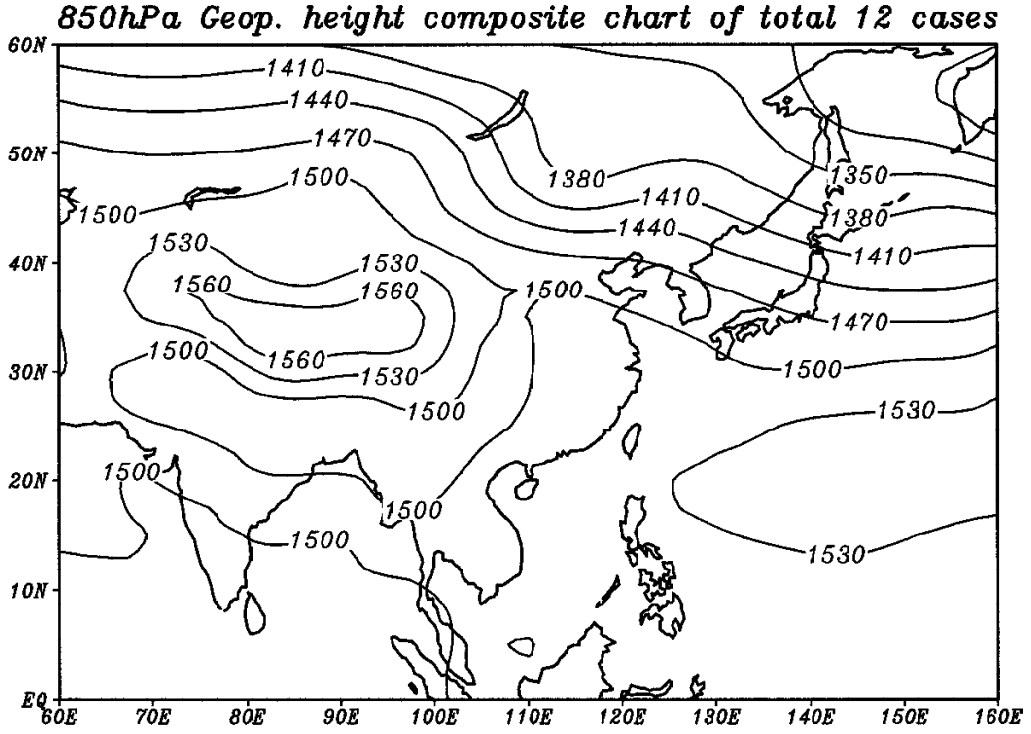

(b)

Fig. 2. The composite charts of geopotential height of Group1 over (a)1000 hPa, (b) $850 \mathrm{hPa},(\mathrm{c}) 700 \mathrm{hPa}$ and (d) $500 \mathrm{hPa}$ 


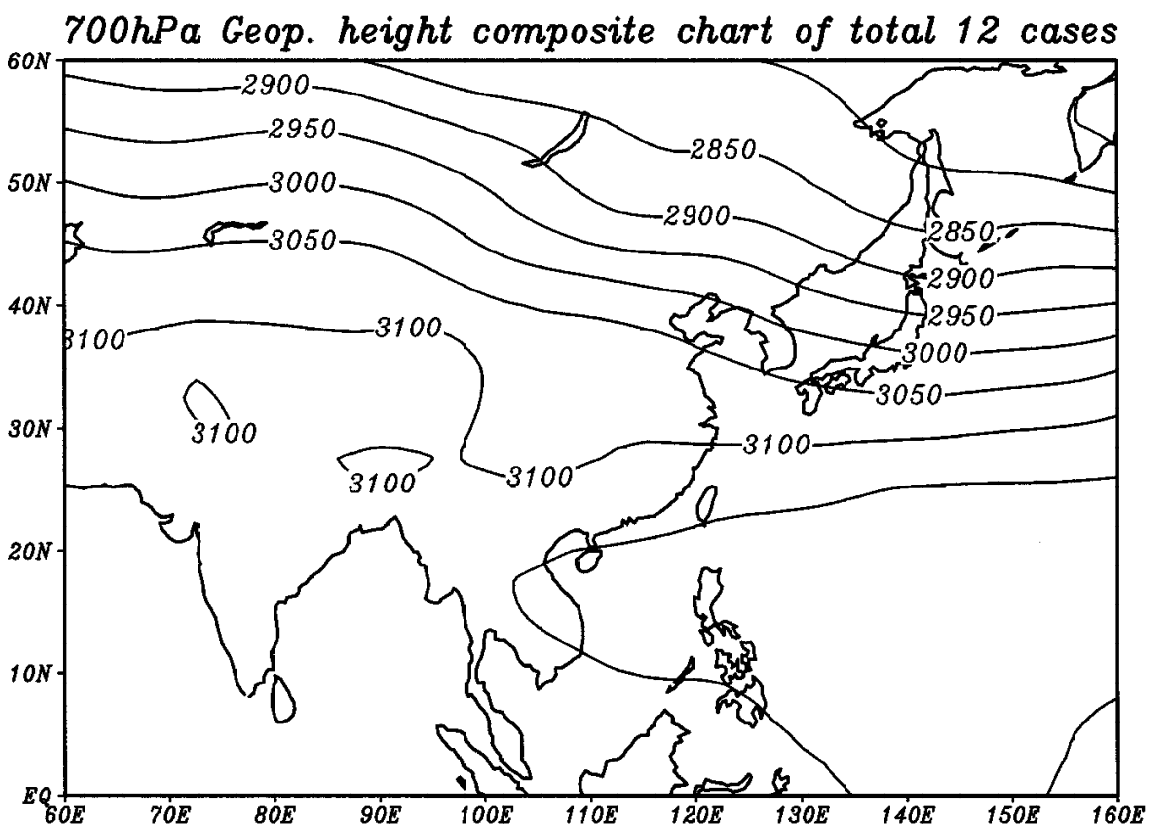

(c)

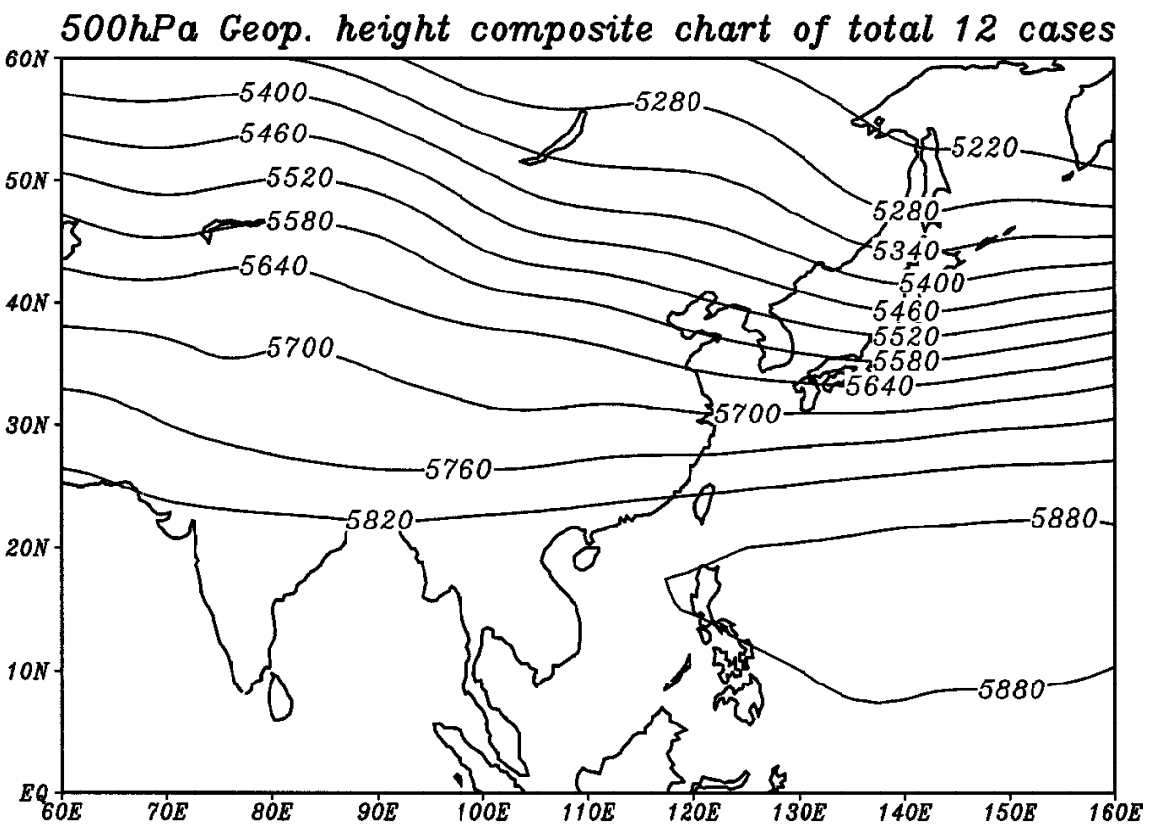

(d)

(Fig. 2 continued) 


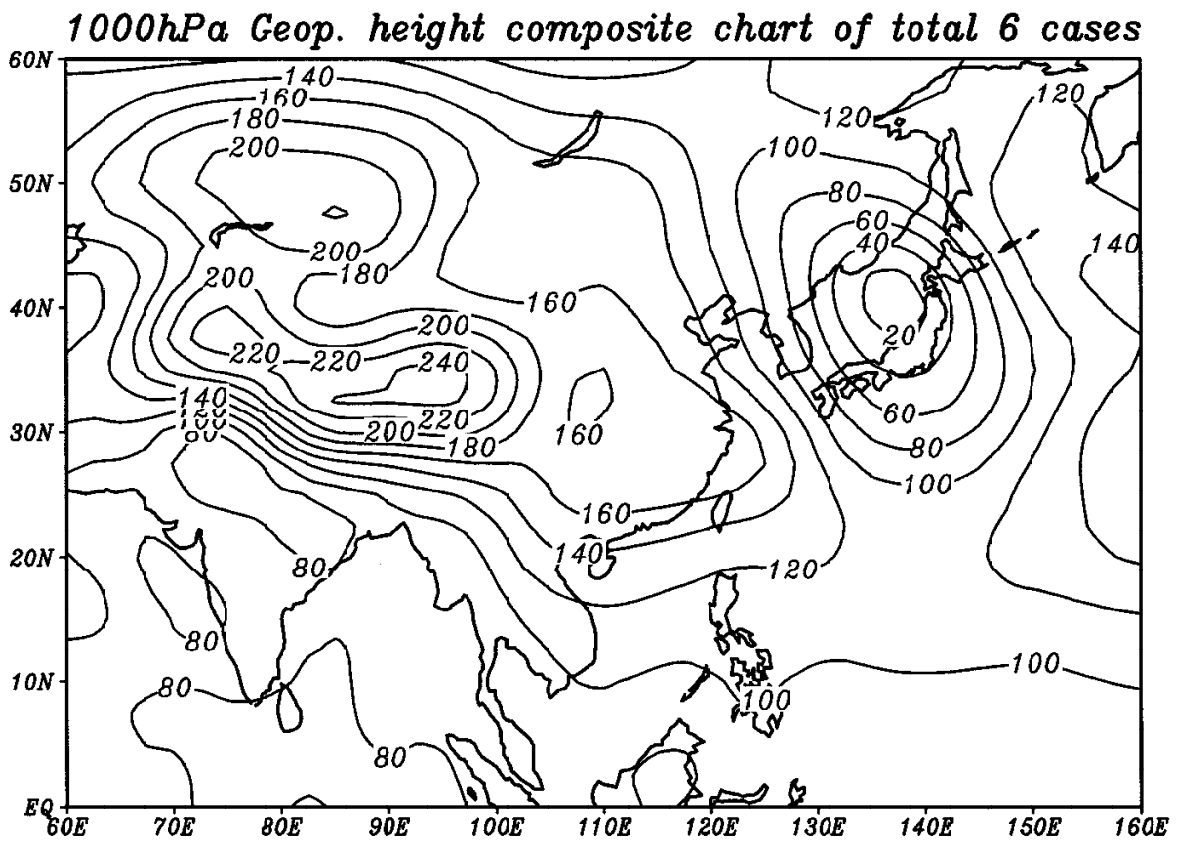

(a)

850hPa Geop. height composite chart of total 6 cases

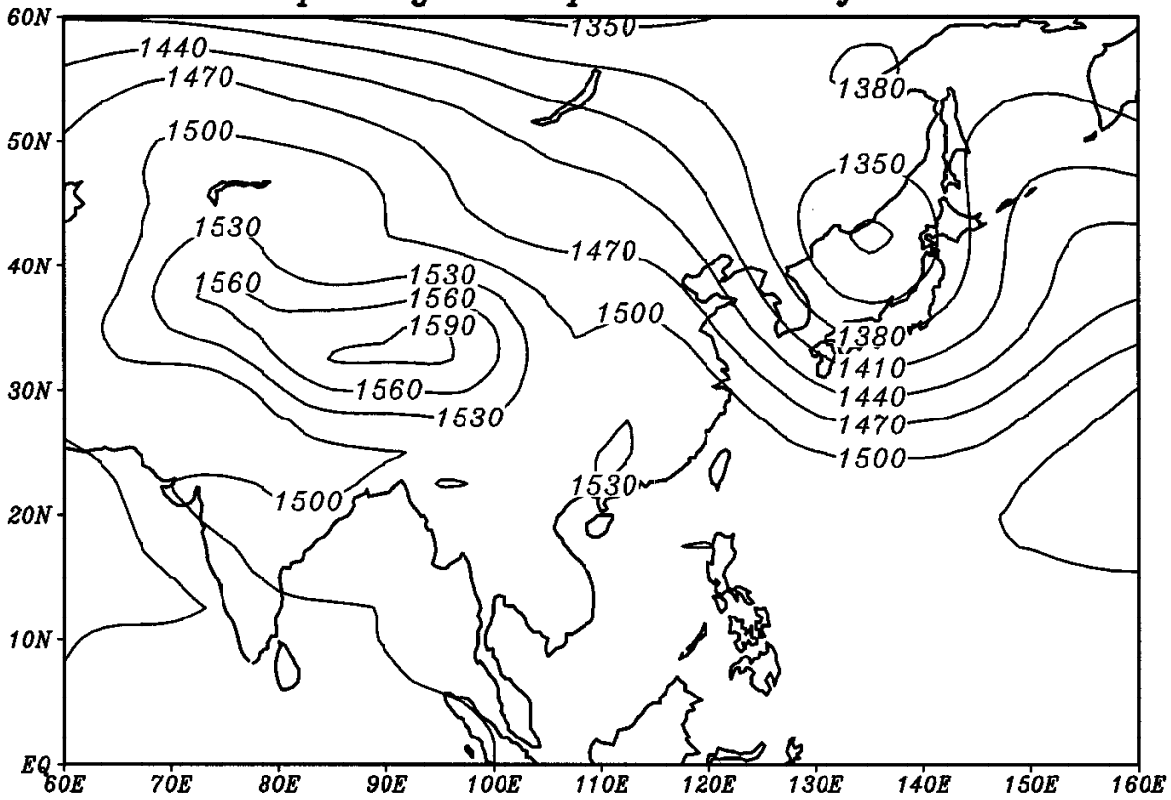

(b)

Fig. 3. The composite charts of geopotential height of Group 2 over (a) $1000 \mathrm{hPa}$, (b) $850 \mathrm{hPa}$, (c) $700 \mathrm{hPa}$ and (d) $500 \mathrm{hPa}$. 
700hPa Geop. height composite chart of total 6 cases

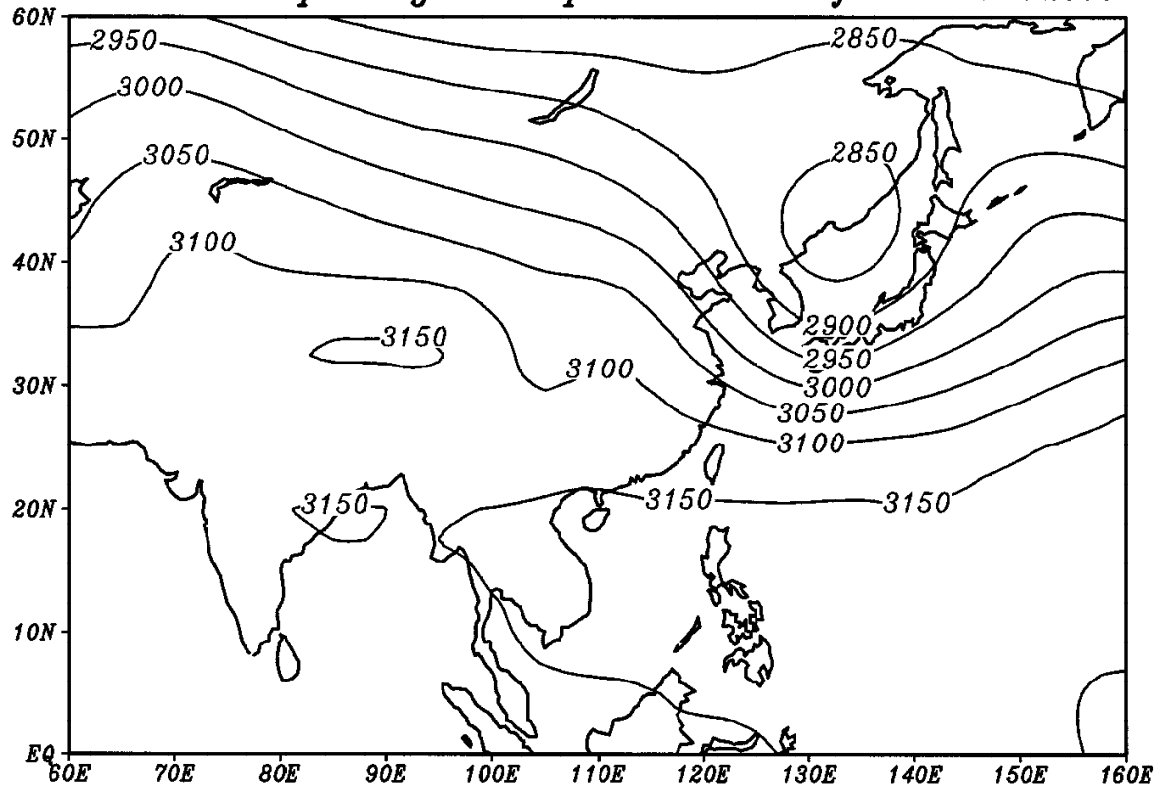

(c)

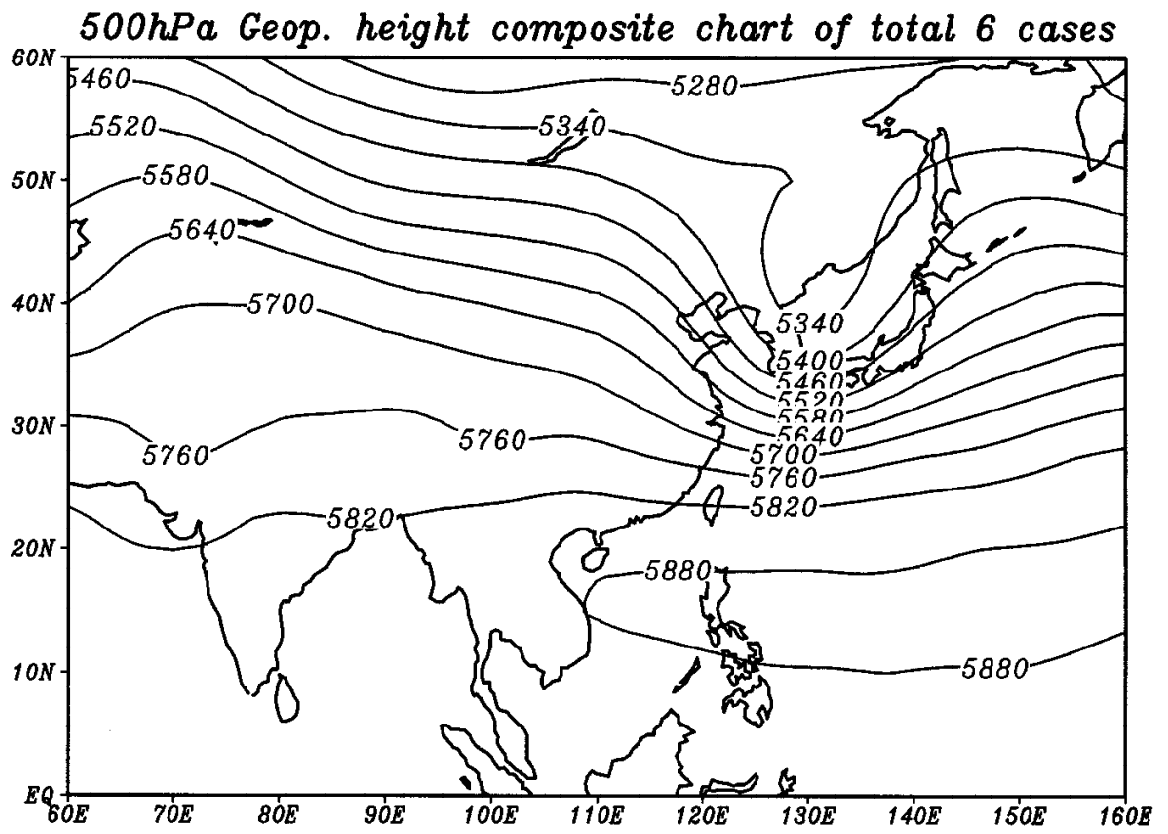

(d)

(Fig. 3 continued) 
Table 2. Synoptic conditions of the cases affecting Taipei (Fig. 3) or Beijing (Fig. 2).

\begin{tabular}{|c|c|c|c|}
\hline Level & Terms & Cases affect Taipei & Cases affect Beijing \\
\hline \multirow{3}{*}{$\begin{array}{l}1000 \\
\mathrm{hPa}\end{array}$} & $\begin{array}{l}\text { 1. Location of the major } \\
\text { high and strength }\end{array}$ & $\begin{array}{l}33^{\circ} \mathrm{N}, 95^{\circ} \mathrm{E} \\
240 \mathrm{gpm}\end{array}$ & $\begin{array}{l}34^{\circ} \mathrm{N}, 95^{\circ} \mathrm{E} \\
220 \text { gmp }\end{array}$ \\
\hline & $\begin{array}{l}\text { 2. Location of the } \\
\text { thermal low and } \\
\text { strength }\end{array}$ & $\begin{array}{c}32^{\circ} \mathrm{N}, 108^{\circ} \mathrm{E} \\
160 \mathrm{gpm}\end{array}$ & $\begin{array}{l}\text { a } \Omega \text {-shape trough, } \\
140 \text { gpm extends } \\
\text { from } 25^{\circ} \mathrm{N}, 108^{\circ} \mathrm{E} \text { to } \\
32^{\circ} \mathrm{N}, 106^{\circ} \mathrm{E}\end{array}$ \\
\hline & 3. Major ridge & $\begin{array}{l}\text { Ridge extended from } \\
\text { mainland to cover } \\
\text { Taiwan and its vicinity }\end{array}$ & $\begin{array}{l}\text { Taiwan and it's } \\
\text { vicinity is covered by } \\
\text { east to southeast } \\
\text { trade wind }\end{array}$ \\
\hline \multirow{3}{*}{$\begin{array}{l}850 \\
\mathrm{hPa}\end{array}$} & 1. Location of the major & $32^{\circ} \mathrm{N}, 90^{\circ} \mathrm{E}$ & $32^{\circ} \mathrm{N}, 90^{\circ} \mathrm{E}$ \\
\hline & $\begin{array}{l}\text { high and strength } \\
\text { 2. Location of the major } \\
\text { low and trough }\end{array}$ & $\begin{array}{l}1560 \mathrm{gpm} \\
40^{\circ} \mathrm{N}, 135^{\circ} \mathrm{E} \text { from the } \\
\text { low to the east of } \\
\text { Taiwan }\end{array}$ & $\begin{array}{l}\text { Shallow trough along } \\
\text { Japan }\end{array}$ \\
\hline & $\begin{array}{l}\text { 3. Location of the } \\
\text { separate high }\end{array}$ & Over Kangtung area & Non existent \\
\hline \multirow{4}{*}{$\begin{array}{l}700 \\
\mathrm{hPa}\end{array}$} & $\begin{array}{l}\text { 1. Location of the high } \\
\text { and strength }\end{array}$ & $\begin{array}{l}31^{\circ} \mathrm{N}, 90^{\circ} \mathrm{E} \\
3150 \mathrm{gpm}\end{array}$ & Non existent \\
\hline & $\begin{array}{l}\text { 2. Location of the short } \\
\text { trough and tilt }\end{array}$ & $\begin{array}{l}\text { A weak positive tilted } \\
\text { trough at about } 30^{\circ} \text {, } \\
105^{\circ} \mathrm{E}\end{array}$ & $\begin{array}{l}\text { A positive tilted } \\
\text { trough extends from } \\
35^{\circ} \mathrm{N}, 105^{\circ} \mathrm{E} \text { to } 24^{\circ} \mathrm{N}, \\
95^{\circ} \mathrm{E}\end{array}$ \\
\hline & $\begin{array}{l}\text { 3. Location of the major } \\
\text { trough }\end{array}$ & $\begin{array}{l}\text { From a low center at } \\
40^{\circ} \mathrm{N}, 135^{\circ} \mathrm{E} \text { down to } \\
\text { the northeast of } \\
\text { Taiwan }\end{array}$ & Almost non existent \\
\hline & 4. Pacific high & $\begin{array}{l}\text { Axis along } \sim 15^{\circ} \mathrm{N} \text { and } \\
\text { extends to Viet } \mathrm{Nan}\end{array}$ & $\begin{array}{l}\text { Similar, but axis is a } \\
\text { little southward }\end{array}$ \\
\hline $\begin{array}{l}500 \\
\mathrm{hPa}\end{array}$ & The major trough & $\begin{array}{l}\text { From the north of } \\
\text { Japan to the northeast } \\
\text { of Taiwan }\end{array}$ & $\begin{array}{l}\text { Very weak trough } \\
\text { over north Japan }\end{array}$ \\
\hline
\end{tabular}




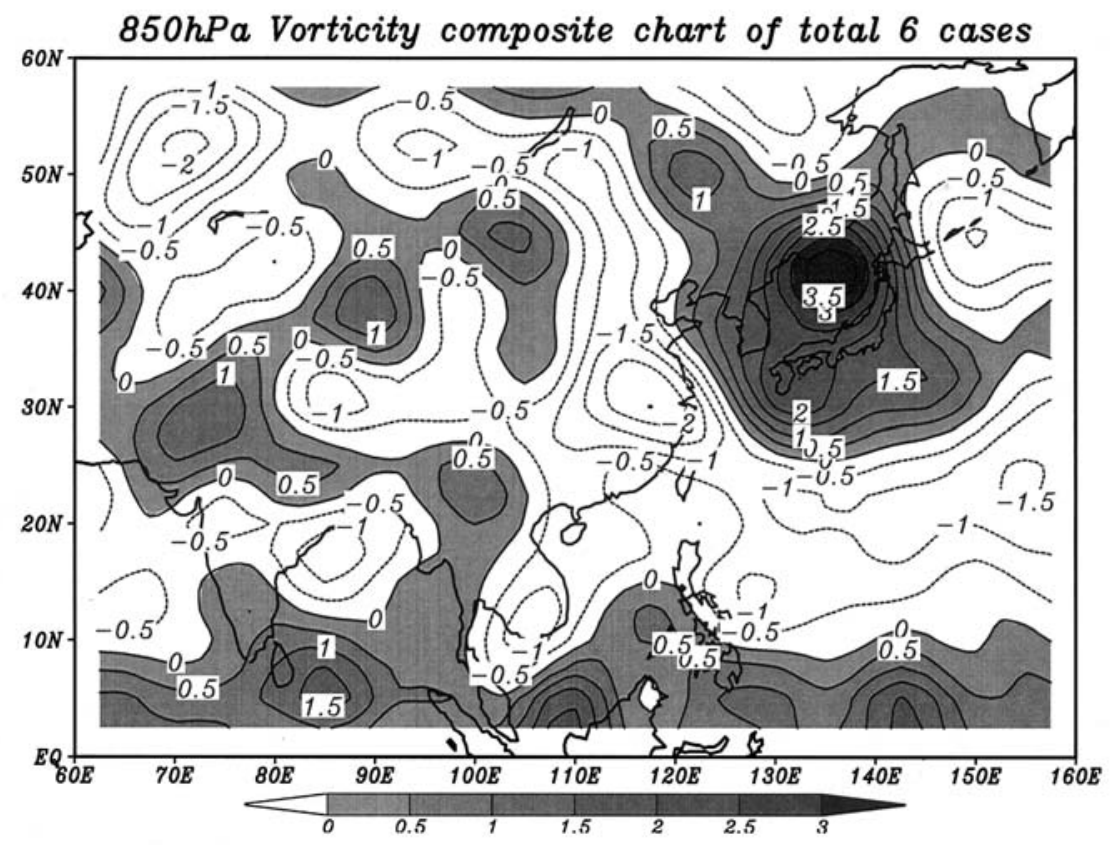

Fig. 4. Composite vorticity of 850 hpa mean spatial distribution of Group 1.

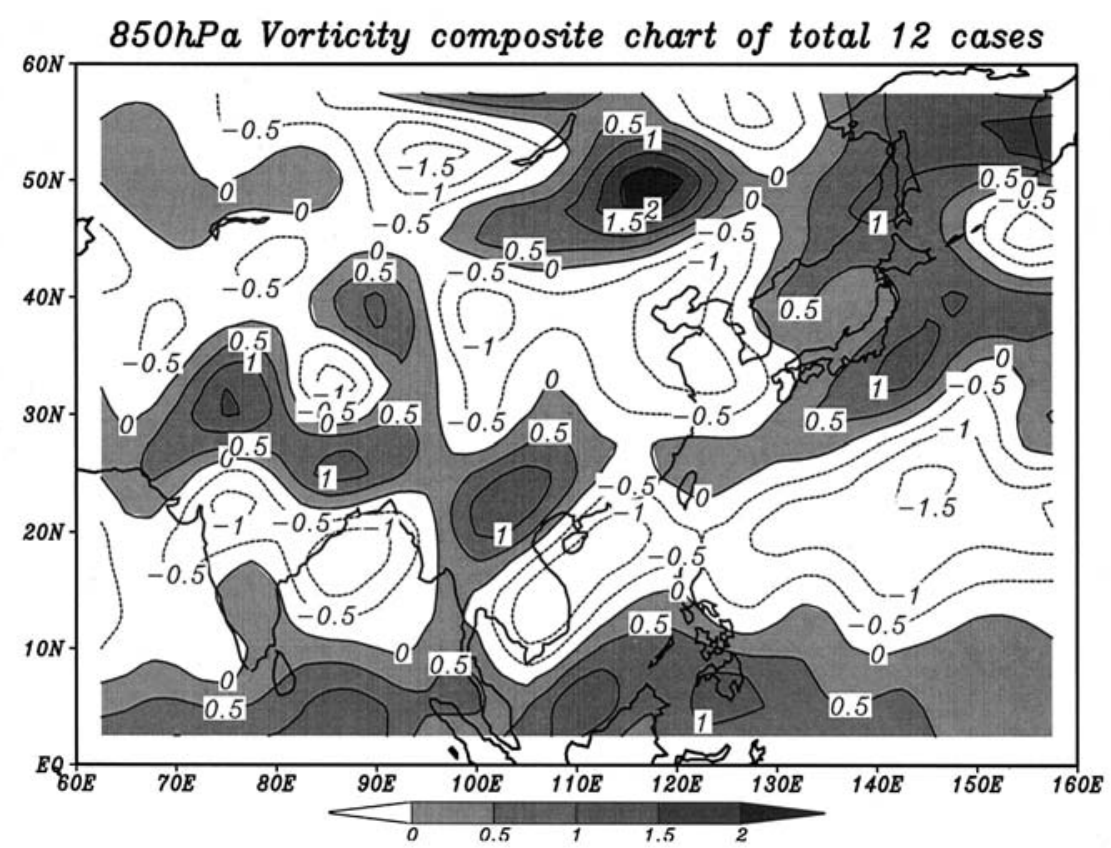

Fig. 5. Composite vorticity of 850 hpa mean spatial distribution of Group 2. 


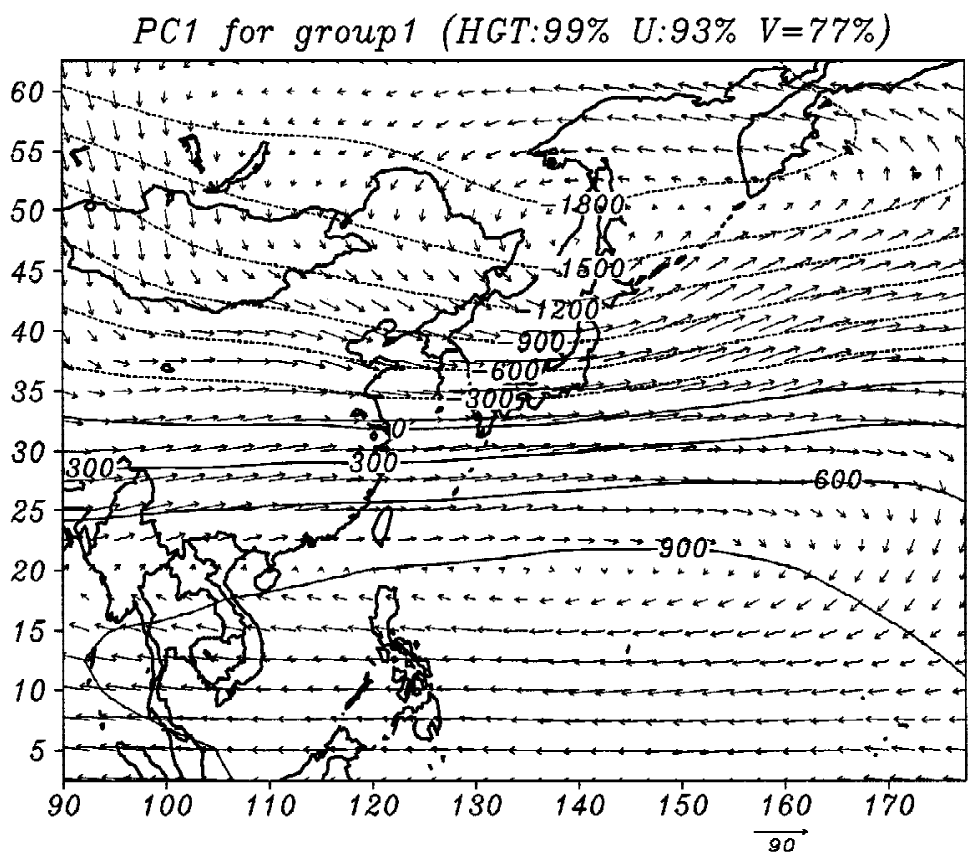

(a)

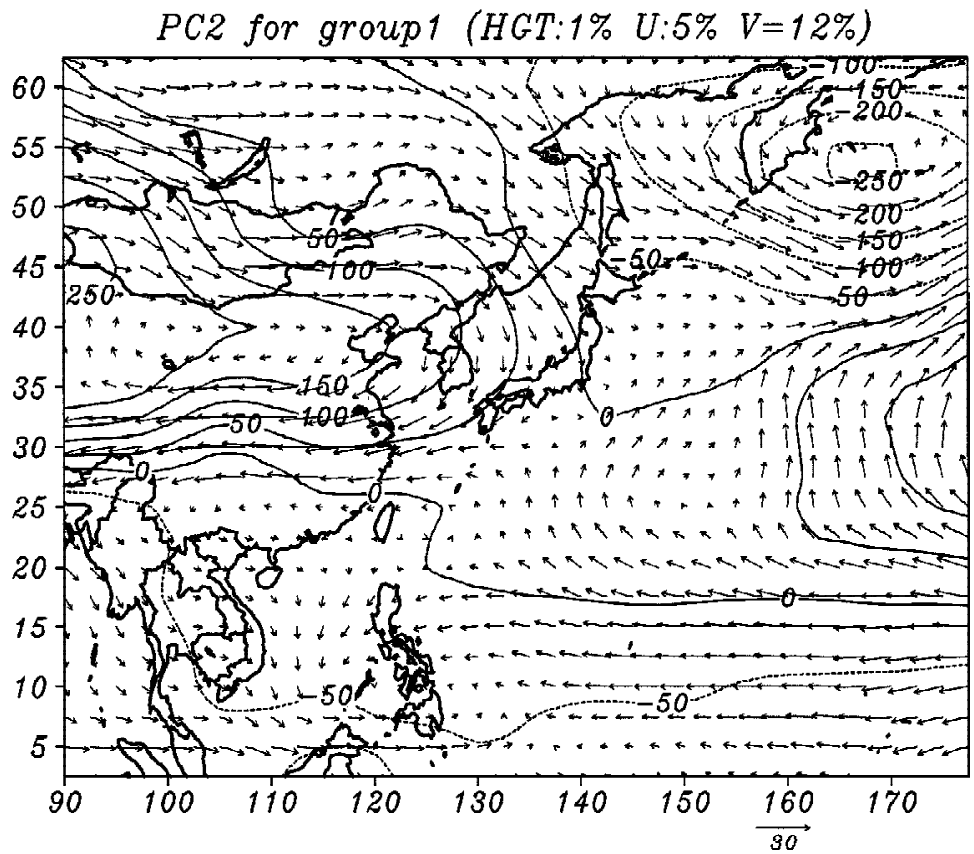

(b)

Fig. 6. The composite PC1(a) and PC2(b) Charts of Group 1. 


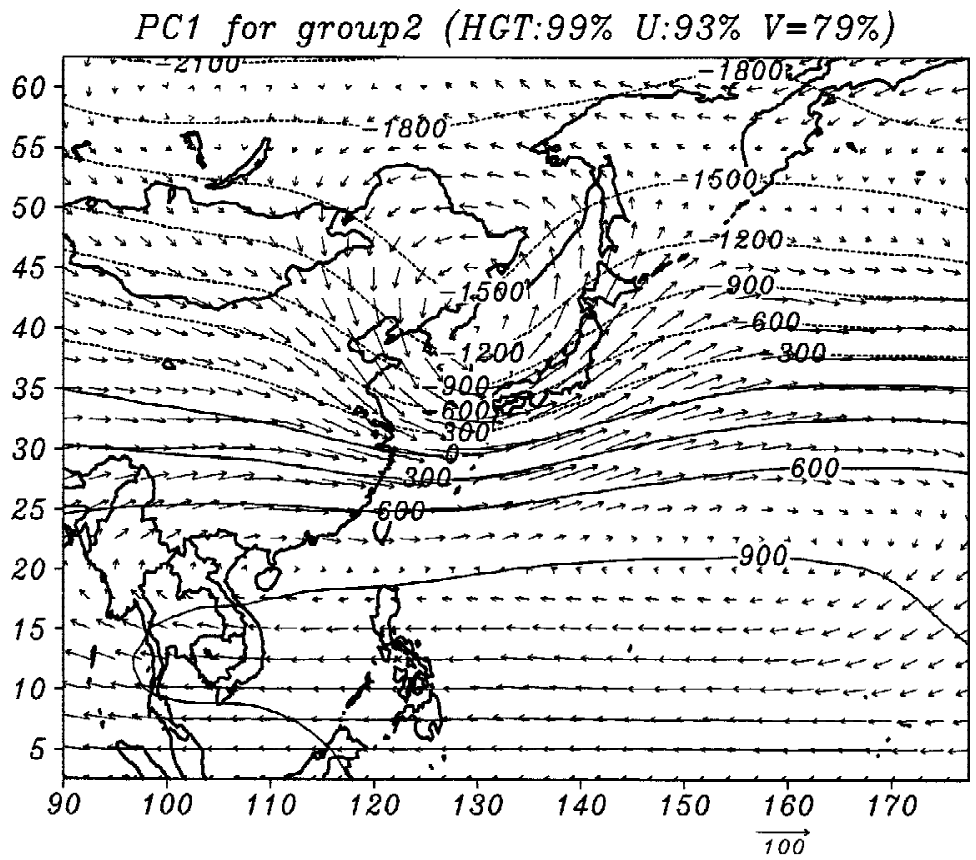

(a)

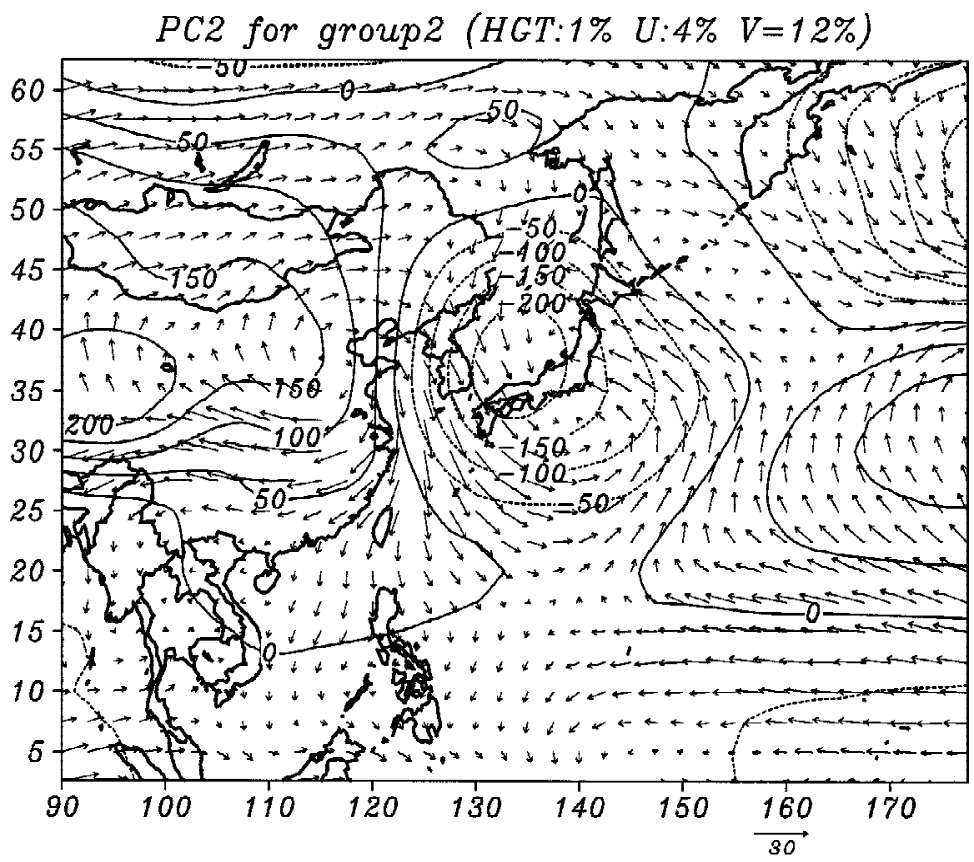

(b)

Fig. 7. The composite PC1(a) and PC2(b) Charts of Group 2. 


\section{CONCLUDING REMARKS}

The region from Sinjiang to Inner Mongolia in China, the furthest removed from the sea and blocked by the Tibet Plateau, receives less rain. Dryness and desertification therefore has been a historical problem. It is generally accepted that blowing dust from upstream formed the Loess Plateau and that millions of tons of dust are deposited downstream and into the sea, fertilizing the water and seabed, which supports an array of living things. Dust events also have adverse effects however on visibility and health. Although only some of the dust storms originating from Mainland China affect Taiwan, they are a serious problem (Chang and Young 2002; Lee and Liu 2004). This composite and comparative study of cases that influence Taipei and Beijing indicate that the position coverage of the continental high, and its counterpart, the thermal low in front of the high, are key factors of the occurrence of the BD event. Thereafter, the lower tropospheric troughs along the east coast of China and the Pacific high ridge play a major role in the process of transportation. The comparative items of the synoptic factor are summarized in Table 2. The differences of relative vorticity distribution and the PC configuration between the two groups were also discussed. Principal components, PC1 and PC2 indicated that both the major trough and the northern wind are much stronger for cases, which affect Taipei than Beijing.

Acknowledgements Suggestions of reviewers and editors and their hard work are deeply appreciated. This work is partly supported by EPA and NSC under contracts EPA -91-L10502-217 and NSC 92-2625-Z-034-003, respectively.

\section{REFERENCES}

Barry, R. G., and A. H. Parry, 1974: Synoptic meteorology. Academic Press, New York, U.S.A. Carlson, T. N., 1994: Mid-latitude Weather systems. Routledge, U.S.A.

Chang, S. S., and C. Y. Young, 2002: The influence of dust storm to the air quality in Taiwan. Proc. Dust Storm. Taipei, 169-191. (in Chinese)

Chen, G. T. J., and H. J. Chen, 1987: Study on large-scale features of dust storm system in East Asia. Meteor. Res., 10, 57-79.

Chen, J. P., Z. Wang, C. Y. Young, F. Tsai, I. C. Tsai, G. J. Wang, W. C. Shien, H. W. Lin, and J. Y. Huang and M. J. Lu, 2004: Simulation of Asian yellow dust incursion over Taiwan for the Spring of 2002 and 2003. TAO, 15, 949-981.

Chen, C. T. Arthur, and J. K. Wann, 2004: Factors regulating the distribution of elements in the sediments of a seasonally anoxic lake in tropical Taiwan. TAO, 15, 785-811.

Chien, C. A., Y. Tsay, C. M. Liu, C. T. Liu, T. L. Liu, and M. H. Xun, 2002: On the dust storms of Northern China. Proc. Dust Storm. Taipei, 79-98. (in Chinese)

Chou, C. C. K., C. Y. Lin, T. K. Chen, S. C. Hsu, S. C. Lung, S. C. Liu, and C. Y. Young, 2004: Influence of long-range transport dust particles on local air quality: A case study on the Asian dust episodes in Taipei during the Spring of 2002.TAO, 15, 881-899. 
Duce, R. A., C. K. Unni, B. J. Ray, J. M. Prospero, and J. T. Merrill, 1980: Long-range atmospheric transport of soil dust from Asia to the tropical North Pacific: temporal variability. Science, 209, 1522-1524.

Hess, S. M., 1959: An introduction to atmospheric physics. Academic Press, U.S.A.

Holmes, H., 2001: The Secret Life of Dust. John Wiley \& Sons, Inc. New York, U.S.A.

Hsiao, L. F., T. F. Wang, and K. Y. Liu, 2001: A study of numerical simulation of dust storm and its long-rang transport to Taiwan. Hwa Kang J. Sci., 18, 1-20. (in Chinese)

Hsu, S. C., S. C. Liu, C. Y. Lin, R. T. Hsu, Y. T. Huang, and Y. W. Chen, 2004: Metal composition of $\mathrm{PM}_{10}$ and $\mathrm{PM}_{2.5}$ aerosols in Taipei during Spring, 2002. TAO, 15, 925-948.

Lee, C. S., 1998: Meteorological analysis and forecast for the high density of aerosol due to dust event. EPA-87-E3L1-03-01. (in Chinese)

Lee, C. S., and H. C. Hsu, 1998: The long-range transport of the air pollution episodes in Taiwan-the long-range transport of dust from Mainland. Itl. Symp. on environ. monitoring infor. manag., Apr. 20-21, Taipei.

Lee, H. C., and C. M. Liu, 2004: Coping with dust storm events: information, impacts and policymaking in Taiwan. TAO, 15, 1035-1060.

Lin, C. Y., S. C. Liu, C. C. K. Chou, T. H. Liu, C. T. Lee, C. S. Yuan, C. J. Shiu, and C. Y. Young, 2004: Long-Range Transport of Asian Dust and Air Pollutants to Taiwan.TAO, 15, 759-784.

Liu, G. R., and T. H. Lin, 2004: Application of geostationary satellite observations for monitoring dust storms of Asian. ibid.

Liu, C. M., 2002: Dust storms and the air quality in Taiwan. Proc. Conf. on Dust Storms. Taipei, 55-78. (in Chinese)

Liu, J. T., X. G. Jiang, X. J. Zheng, L. Kang, and F. Y. Qi, 2004: An intensive mongolian cyclone genesis induced severe dust storm. TAO, 15, 1019-1033.

Liu, K. Y., Z. Wang, and L. F. Hsiao, 2002: A sensitivity study of the blowing dust mechanism. Proc. Dust Storm. Taipei, 15-47. (in Chinese)

Palmen, E., and C. W. Newton, 1969: Atmospheric circulation systems, their structure and physical interpretation, Academic Press, USA.

Parrington, J. R., Zoller, W. H., and Aras, N. K., 1983: Asia dust: seasonal transport to Hawaii Islands. Science, 220, 195-197.

Wang, Z., H. Ueda, and M. Huang, 2000: A deflation module for use in modeling long-range transport of yellow sand over East Asia.J. Geophy. Res., 105, 26947-26960.

Xiao, B. Y., C. A. Chien, and Y. J. Chiao, (1997: A composite study of the first five heavy dust storms occurred in northwest of China. Dust studies, Beijing. (in Chinese)

Yu, C. Y., C. Y. Chen, and K. Y. Liu, 1996: Air quality in Taiwan and its relationship to dust storm. Scientific report, EPA, Taipei. (in Chinese).

Yuan, C. S., C. C. Sau, M. C. Chen, M. H. Huang, S. W. Chang, Y. C. Lin, and C. G. Lu, 2004: Mass concentration and size-resolved chemical composition of atmospheric aerosols sampled at Pescadores Islands during Asian dust storm periods in the years of 2001 and 2002. TAO, 15, 857-879. 